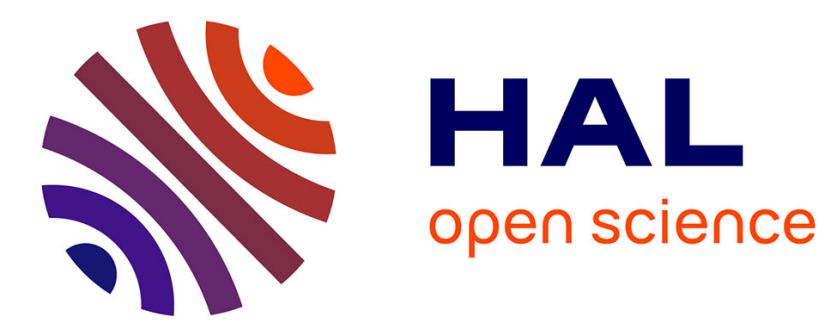

\title{
I3-Ag85 effect on phthiodiolone dimycocerosate synthesis
}

Céline Rens, Françoise Laval, Ruddy Wattiez, Philippe Lefèvre, François

Dufrasne, Mamadou Daffe, Véronique Fontaine

\section{To cite this version:}

Céline Rens, Françoise Laval, Ruddy Wattiez, Philippe Lefèvre, François Dufrasne, et al.. I3Ag85 effect on phthiodiolone dimycocerosate synthesis. Tuberculosis, 2018, 108, pp.93-95. 10.1016/j.tube.2017.10.007 . hal-02352260

\section{HAL Id: hal-02352260 \\ https://hal.science/hal-02352260}

Submitted on 12 Nov 2019

HAL is a multi-disciplinary open access archive for the deposit and dissemination of scientific research documents, whether they are published or not. The documents may come from teaching and research institutions in France or abroad, or from public or private research centers.
L'archive ouverte pluridisciplinaire HAL, est destinée au dépôt et à la diffusion de documents scientifiques de niveau recherche, publiés ou non, émanant des établissements d'enseignement et de recherche français ou étrangers, des laboratoires publics ou privés. 


\section{I3-Ag85 effect on phthiodiolone dimycocerosate synthesis}

2 Céline Rens ${ }^{\mathrm{a}}$, Françoise Laval ${ }^{\mathrm{b}}$, Ruddy Wattiez ${ }^{\mathrm{c}}$, Philippe Lefèvre ${ }^{\mathrm{a}}$, François Dufrasne ${ }^{\mathrm{d}}$,

3 Mamadou Dafféb and Véronique Fontaine

4

5

\# Address correspondence to Véronique Fontaine, vfontain@ulb.ac.be

Keywords: Mycobacterium tuberculosis, I3-Ag85, TDM, PDIM

Abbreviations: TDM: trehalose dimycolate, PDIM A: phthiocerol dimycocerosate, PDIM B: phthiodiolone dimycocerosate, MDR: multi-drug-resistant, XDR: extensively-drug-resistant, Mtb: Mycobacterium tuberculosis, SL: sulfolipids, DAT: diacyltrehalose, PAT: polyacyltrehalose, TMM: trehalose monomycolate, MIC: minimal inhibitory concentration, FICI: fractional inhibitory concentration index, $k o$ : knock-out, wt: wild-type, HP-TLC: High performance thin layer chromatography, MAME: mycolic acid methyl esters, AcPIM: acyl phosphatidylinositol mannoside, TAG: triacylglycerol 
30 The multiplicity of drug resistant Mycobacterium tuberculosis (Mtb) strains is a growing health 31 issue. New therapies are needed, acting on new targets. The I3-Ag85 was already reported to reduce the amount of trehalose dimycolate lipid of the mycobacterial cell wall. This inhibitor of Ag85c increased the mycobacterial wall permeability. We previously showed that $M$. tuberculosis strains, even multi-drug resistant and extensively-drug resistant strains, can be susceptible to vancomycin when concomitantly treated with a drug altering the cell envelope integrity. We investigated the effect of the I3-Ag85 on vancomycin susceptibility of $M$. tuberculosis. Although no synergy was observed, a new target of this drug was discovered: the production of phthiodiolone dimycocerosate (PDIM B). 
The emergence of multi- and extensively drug resistant (MDR and XDR) Mycobacterium tuberculosis (Mtb) strains emphasized the urgent need for new antitubercular drug development [1]. In this perspective, we focused on drugs targeting the external lipid envelope of these bacteria. Mtb, the main causative agent of tuberculosis, has a particular waxy cell wall outward its peptidoglycan layer. The very long chain fatty acids, up to $\mathrm{C} 100$ and called mycolic acids, are attached to arabinogalactan, which in turn is covalently bound to peptidoglycan. The giant complex macromolecule interact with extractable waxy lipids, forming a hydrophobic wall [2]. Among these complex lipids, trehalose dimycolate (TDM), sulfolipids (SL), diacyltrehalose (DAT), penta- or poly-acyltrehalose (PAT) and phthiocerol- or phthiodiolone dimycocerosate (PDIM A and PDIM B) are virulence factors important for host interaction. Additionally, both TDM and PDIM play an important structural role. TDM, known as "cord factor", is involved in the host's immune system modulation during granuloma formation, but it is also involved in the mycobacteria wall impermeability, conferring protection against drug entrance [3, 4]. PDIM A and PDIM B have been shown to be involved in mycobacterial wall impermeability against drugs, oxidative stresses and SDS [5-9].

The large molecular size of the glycopeptides prevents them from penetrating the waxy Mtb cell wall. However, in previous articles, we showed that drugs inhibiting PDIM synthesis could increase the inhibitory action of vancomycin on Mtb $[9,10]$. The report of Warrier et al., on a TDM inhibitor specifically targeting the Ag85C on MDR and XDR Mtb clinical strains and able to improve Mtb permeability to glycerol, raised our attention [11]. The Ag85C is part of an enzymatic complex including Ag85A and Ag85B, and the most active enzyme involved in the transfer of mycolic acid residues, carried by trehalose monomycolate (TMM), on arabinogalactan [12].

Based on Warrier et al. results, we tested the susceptibility of Mtb to vancomycin in the presence of this inhibitor, I3-Ag85, in order to investigate a potential synergistic effect of this combination [11]. The I3-Ag85 was synthetized as previously described [13]. We performed drug susceptibility assay following the agar proportion method on the Mtb H37Rv strain [14]. Vancomycin and I3-Ag85 were serially diluted alone or in combination in 24-well plates and inoculated with $10 \mu 10^{-1}$ to $10^{-4}$ dilutions of McFarland No. 1 turbidity culture. The obtained minimal inhibitory concentration (MIC) were used to calculate the fractional inhibitory concentration index (FICI) following the Checkerboard method: $\mathrm{FICI}=\mathrm{MIC}_{\mathrm{ab}} / \mathrm{MIC}_{\mathrm{a}}+$ $\mathrm{MIC}_{\mathrm{ba}} / \mathrm{MIC}_{\mathrm{b}}$ [15]. $\mathrm{MIC}_{\mathrm{a}}$ were $50 \mu \mathrm{g} / \mathrm{ml}$ for vancomycin and $\mathrm{MIC}_{\mathrm{b}}$ was $44 \mu \mathrm{g} / \mathrm{ml}$ for I3-Ag85. Vancomycin serially diluted with $4.4 \mu \mathrm{g} / \mathrm{ml} \mathrm{I3-Ag85} \mathrm{fix} \mathrm{concentration} \mathrm{still} \mathrm{gave} \mathrm{an} \mathrm{MIC}_{\mathrm{ab}}$ of 
$50 \mu \mathrm{g} / \mathrm{ml}$ vancomycin. Similarly, I3-Ag85 serially diluted with $10 \mu \mathrm{g} / \mathrm{ml}$ vancomycin fixed concentration gave a $\mathrm{MIC}_{\text {ba }}$ of $44 \mu \mathrm{g} / \mathrm{ml} \mathrm{I3-Ag85}$. A FICI of 2 was obtained, showing no synergistic effect of the two drugs.

Since these results suggested that the I3-Ag85 targets, including Ag85C [11], are not involved in vancomycin resistance, we verified the vancomycin susceptibility by the agar proportion method of a strain lacking this enzyme (KO), MT0137, obtained by transposon insertion, compared to the CDC1551 wild type Mtb strain (WT) [16]. The absence of the expression of the Ag85C in the MT0137 strain was confirmed by proteomic analysis (Fig. S1). In contrast to the WT strain, no specific peptide corresponding to the Ag85c was identified and sequenced from the KO sample. The WT and KO strains showed similar MIC for vancomycin (50-200 $\mu \mathrm{g} / \mathrm{ml}$ for the WT and $100-200 \mu \mathrm{g} / \mathrm{ml}$ for the $\mathrm{KO}$ ). Considering that the vancomycin susceptibility was unchanged in the KO strain compared to WT strain, we considered that $\mathrm{Ag} 85 \mathrm{C}$ is not an interesting target to potentiate glycopeptide effect. It is worth noting that we observed the same susceptibility to the I3-Ag85 (22-44 $\mu \mathrm{g} / \mathrm{ml})$ in both strains, as previously reported by Warrier et al. [11].

I3-Ag85 inhibitory effect should therefore rely on the inhibition of additional targets, including potentially orthologous Ag85A or B proteins, given that the $\mathrm{KO}$ strain is devoid of $\mathrm{Ag} 85 \mathrm{C}$ but shows the same MIC to the inhibitor as the WT strain. We therefore analyzed their lipid composition by high-pressure thin-layer chromatography (HPTLC) as previously described [10], comparing midlog-phase growing Mtb CDC1551 WT and KO cultures (with inoculum size 100 fold higher compared to drug susceptibility assays), treated or untreated $24 \mathrm{~h}$ with 44 $\mu \mathrm{g} / \mathrm{ml}$ I3-Ag85 [17]. As described by Warrier et al., we observed a slight decrease of TDM and an increase of DAT+TMM in the treated WT strain (Fig. 1A and B) [11]. Additionally, we observed a decrease of acylated phosphatidylinositol hexamannoside $\left(\mathrm{Ac}_{2} \mathrm{PIM}_{6}\right)$ and an increase of phosphatidyl ethanolamine (PE) (Fig. 1A and B). Although both the I3-Ag85 treated $\mathrm{KO}$ and the WT strains showed an increase of DAT+TMM, the mutant additionally exhibited a decrease of the triacylglycerol (TAG) and PDIM B (Fig. 1A and C). This decrease of PDIM B by the I3-Ag85 treatment in the KO strain is highlighted by the stronger PDIM B HPTLC signal intensity compared to the untreated WT strain (Fig. 1A).

As reported by Warrier et al, mycolic acid methyl esters (MAME) were not notably changed by the I3-Ag85 treatment, suggesting that other enzymes, including the orthologous $\mathrm{Ag} 85 \mathrm{~A}$ or B proteins could rescue mycolic acid transfer on arabinogalactan (data not shown). Considering 
105 that Warrier et al. also reported a free mycolic acid change, these authors suggested that a 106 specific effect on the TDM synthesis by this inhibitor [11].

107 Our lipid analyses, especially on the KO strain lacking Ag85C, suggest that the I3-Ag85 has an 108 additional effect by reducing the PDIM B production, either directly or indirectly . Indeed, a 109 change in the balance between an acetyl-CoA derived lipid (e.g. TMM) and a propionyl-CoA 110 derived lipids (e.g. PDIM B), as observed by the I3-Ag85 treatment, has been already reported 111 in a $\Delta m c e 1 \mathrm{KO}$ mutant strain [18]. Propionyl-CoA derived lipid synthesis could protect bacteria 112 against propionate induced toxicity [2]. The inhibition of PDIM synthesis could therefore be 113 harmful for Mtb and explain the I3-Ag85 susceptibility of both WT and MT0137 $\Delta f b p$ C strains.

\section{ACKNOWLEDGEMENT}

115 Céline Rens was supported by "Les amis des Instituts Pasteurs à Bruxelles" asbl. We thank 116 Alain Baulard for providing us biosecurity level 3 facilities. 


\section{REFERENCES}

[1] World Health Organization. WHO report 2016. Global tuberculosis control.

[2] Daffé, M., Crick, D. and Jackson, M. Genetics of capsular polysaccharides and cell envelope (glyco)lipids. Microbiol Spectrum 2014; 2:MGM2-0021-2013.

[3] Welsh KJ, Abbott AN, Hwang SA, Indrigo J. A role for tumour necrosis factor-alpha, complement C5 and interleukin-6 in the initiation and development of the mycobacterial cord factor trehalose 6,6'-dimycolate induced granulomatous response. Microbiology 2008; 154:1813-24.

[4] Katti MK, Dai G, Armitige LY, Rivera Marrero C. The Delta fbpA mutant derived from Mycobacterium tuberculosis $\mathrm{H} 37 \mathrm{Rv}$ has an enhanced susceptibility to intracellular antimicrobial oxidative mechanisms, undergoes limited phagosome maturation and activates macrophages and dendritic cells. Cell Microbiol 2008; 10:1286-303.

[5] Chavadi SS, Edupuganti UR, Vergnolle O, Fatima I. Inactivation of tesA Reduces Cell Wall Lipid Production and Increases Drug Susceptibility in Mycobacteria. J Biol Chem 2011; 286: $24616-25$

[6] Wang XM, Lu C, Soetaert K, S'Heeren C. Biochemical and immunological characterization of a cpn60.1 knockout mutant of Mycobacterium bovis BCG. Microbiolog 2011; 157:1205-19.

[7] Camacho LR, Constant P, Raynaud C, Laneelle MA. Analysis of the phthiocerol dimycocerosate locus of Mycobacterium tuberculosis. Evidence that this lipid is involved in the cell wall permeability barrier. J Biol Chem 2001; 276:19845-54.

[8] Siméone R, Constant P, Malaga W, Guilhot C. Molecular dissection of the biosynthetic relationship between phthiocerol and phthiodiolone dimycocerosates and their critical role in the virulence and permeability of Mycobacterium tuberculosis. FEBS J 2007; 274:1957-69.

[9] Soetaert K, Rens C, Wang XM, De Bruyn J. Increased Vancomycin Susceptibility in Mycobacteria: a New Approach To Identify Synergistic Activity against Multidrug-Resistant Mycobacteria. Antimicrob Agents Chemother 2015; 59:5057-60.

[10] Rens C, Laval F, Daffé M, Denis O. Effects of Lipid-Lowering Drugs on Vancomycin Susceptibility of Mycobacteria. Antimicrob Agents Chemother 2016; 60:6193-9. 
[11] Warrier T, Tropis M, Werngren J, Diehl A. Antigen 85C Inhibition Restricts

147 Mycobacterium tuberculosis Growth through Disruption of Cord Factor Biosynthesis. 148 Antimicrob Agents Chemother 2012; 56: 1735-43.

149 [12] Jackson M, Raynaud C, Lanéelle MA, Guilhot C. Inactivation of the antigen 85C gene profoundly affects the mycolate content and alters the permeability of the Mycobacterium tuberculosis cell envelope. Mol Microbiol 1999; 31:1573-87.

152 [13] Scheich, C, Puetter, V, Schade, M, Novel Small Molecule Inhibitors of MDR 153 Mycobacterium tuberculosis by NMR Fragment Screening of Antigen 85C. J Med Chem 2010; 53: 8362-7

[14] National Committee for Clinical Laboratory Standards, Wayne, PA. Susceptibility testing of mycobacteria, nocardia, and other aerobic actinomycetes. Approved standard M24-A 2003.

[15] Hsieh MH, Yu CM, Yu VL, Chow JW. Synergy assessed by checkerboard. A critical analysis. Diagn Microbiol Infect Dis 1993; 16:343-9.

[16] Lamichhane G, Zignol M, Blades NJ, Geiman DE, Dougherty A, Grosset J, Broman KW, Bishai WR. A postgenomic method for predicting essential genes at subsaturation levels of mutagenesis: application to Mycobacterium tuberculosis. Proc Natl Acad Sci U S A 2003; 100:7213-8.

[17] Simeone R, Huet G, Constant P, Malaga W. Functional Characterization of Three Omethyltransferases Involved in the Biosynthesis of Phenolglycolipids in Mycobacterium tuberculosis. PLoS One 2013; 8:e58954. metabolic profiling of mce1 operon mutant vs wild-type Mycobacterium tuberculosis strains. Pathog Dis 2015; 73: ftv066. 
172 Fig. 1. HP-TLC analyses of the CDC1551 wt and $\triangle f b p C$ strain lipids. Each experiment was 173 performed at least three times using independent samples. A. HP-TLC migration profiles of 174 lipids in petroleum ether/diethyl ether $(9: 1)$ revealed with phosphomolybdic acid to visualise 175 PDIM (upper panel) or migrated in $\mathrm{CHCl}_{3} / \mathrm{CH}_{3} \mathrm{OH} / \mathrm{H}_{2} \mathrm{O}(60: 35: 8)$ revealed with anthrone to 176 visualise more polar cell wall lipids (lower panel). B. Lipid spots quantification, performed on 177 HP-TLC using primuline for the revelation, for the $w t$ strain, normalized to the total amount of 178 lipids in the I3-Ag85 treated condition compared to the DMSO control (set as 100\%). C. Lipid 179 spots quantification, performed on HP-TLC using primuline for the revelation, for the $\triangle f b p C$ 180 strain, normalized to the total amount of lipids in the I3-Ag85 treated condition compared to 181 the DMSO control. The relative abundance of the different classes of lipids in B. and C. was 182 determined by loading $5 \mu \mathrm{g}$ of lipid mixture onto a HP-TLC silica gel 60 plate (Merck) with a 183 Camag ATS4 apparatus. The plate was developed in the appropriate solvent mixture using a 184 Camag ADC2 device and stained by the reagent with a Camag CID3 apparatus, followed by 185 heating at $150^{\circ} \mathrm{C}$ for $20 \mathrm{~min}$, when necessary. Lipids were quantified by absorption measurement at $400 \mathrm{~nm}$ with a Camag Scanner 3 device using Wincats software. 